International scientific and technical conference

DOI: $10.34185 / 1991-7848 . i t m m .2020 .01 .029$

\title{
СЕЗОННИЙ ВПЛИВ НА РЕЖИМИ РОБОТИ ЕЛЕКТРОТЕХНІЧНОЇ СИСТЕМИ ПРОТИКОРОЗІЙНОГО ЗАХИСТУ
}

\author{
Азюковський О.О. к.т.н., доцент
}

Національний технічний університет «Дніпровська політехніка», Україна

Україна має розгалужену систему газопровідного транспорту. Загалом магістральних газопроводів та газопроводів - відгалужень близько 35700 км., розподільних газопроводів та газопроводів-вводів - 402000 км. [1]. Більшість 3 цих газопроводів є сталевими із терміном експлуатації від 50 років й до поточного часу. За даними Держкомстату України довжина трубопроводів загального користування станом на 01.01.2018 становила 41300 тис.км. [2]. Протикорозійний захист підземного сталевого трубопроводу здійснюється системою катодного захисту $[3,4]$. Параметри та ефективність режимів роботи системи «станція катодного захисту - підземний сталевий трубопровід грунт» визначаються струмами стікання з трубопроводу та загальним струмом трубопроводу [3 - 7]. Опосередковано або, за умови наявності безпосереднього контакту «труба - земля», на силу струмів стікання впливає опір навколишнього середовища протіканню цим струмам. Зміна вологості та температурного режиму зумовлюють зміни у провідності середовища. Так, сезонні зміни струмів станцій катодного захисту (СК3) при фіксованому значенні напруги на виході СКЗ (рис. 1) свідчать про значні сезонні коливання (від 0,5 А. до близько 7 А.). Суттєвих змін у параметрах ділянок підземного сталевого трубопроводу під час проведення вимірювань не відбувалось. Невраховування змін у електротехнічних параметрах навколишнього середовища призводить до нераціональних режимів роботи системи протикорозійного захисту.

Ці відмінності зумовлені змінами в електротехнічних параметрах контактних точок «грунт - сталева труба ». Різниця між значеннями струмів викликана у першу чергу вологістю грунту зумовленою сезонними змінами (опадами). Мінімальне значення як зазвичай припадає на зимовий або літній періоди. Сезонні зміни у провідності грунту викликають необхідність у корегування режимів роботи СКЗ. 


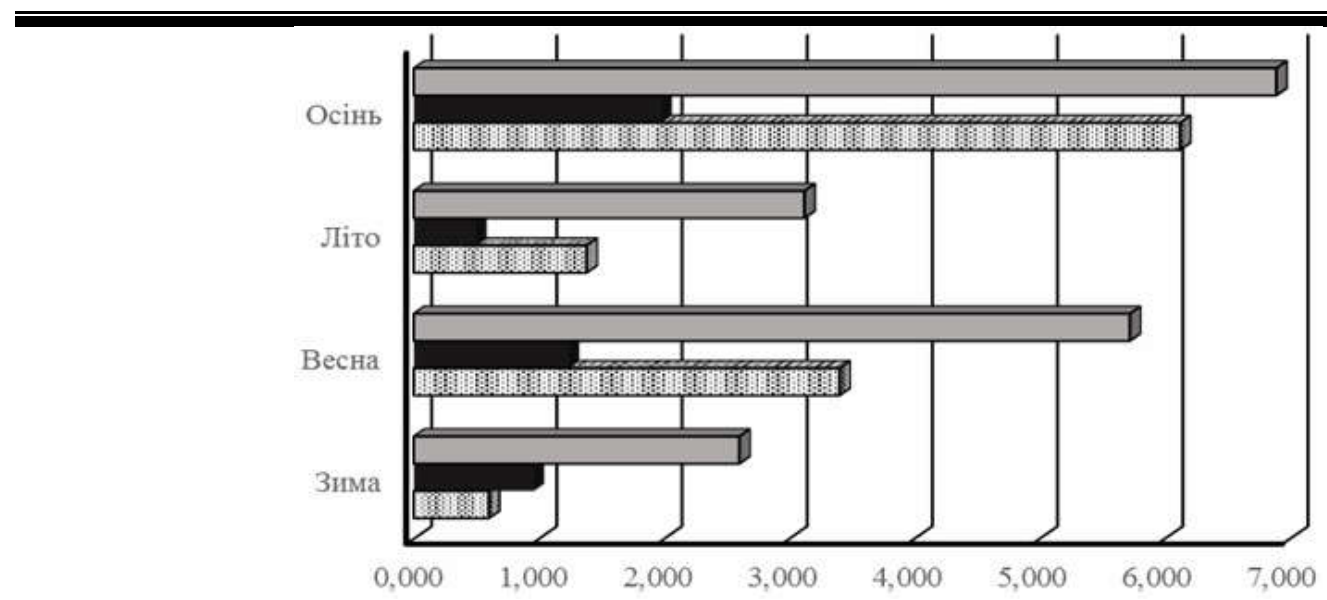

Рисунок 1 - Середні сезонні значення струмів СКЗ при фіксованій їх напрузі

Надлишковий захисний потенціал трубопроводу зумовлює нераціональну витрату електричної енергії та матеріалу анодного заземлювача. Тому потрібна адаптація режимів роботи СКЗ до сезонних змін у електротехнічних параметрах навколишнього середовища [8]. Зміна у параметрах навколишнього середовища відбувається й під впливом погодних умов - опадів, рівнів грунтових вод, техногенного фактору. Автоматичне керування режимами роботами однією СКЗ повністю не вирішує завдання мінімізації нераціонального використання електричної енергії та ресурсів системи протикорозійного захисту. Зважаючи на те, що система підземних сталевих трубопроводів знаходиться під одночасним впливом декількох СКЗ, що гальванічно пов’язані між собою, потрібно сумісне керування їх режимами роботи задля зменшення негативного взаємного впливу СКЗ одна на одну.

\section{Література}

1. «Мережа магістральних і розподільних газопроводів України» [Онлайновий]. Available: https://104.ua/ru/gas-map. [Дата звернення: 0601 2020].

2. «Державна служба статистики України,» [Онлайновий]. Available: http://www.ukrstat.gov.ua/. [Дата звернення: 0801 2020]

3. Стрижевский И. В. Теория и расчет влияния электрифицированной железной дороги на подземные металлические сооружения./ И.В. Стрижевский, В.И. Дмитриев. - М.: Машиностроение, 1967 - 227с.

4. Азюковський О.О. Зміна електротехнічних параметрів підземного металевого трубопроводу під впливом високочастотної складової напруги станцій катодного захисту / О.О. Азюковський // Електрифікація транспорту. Дніпропетровський 
International scientific and technical conference Information Technologies in Metallurgy and Machine building - ITMM 2020

національний університет залізничного транспорту імені академіка В. Лазаряна. № 10, 2015. с. $98-106$

5. Aziukovskyi O. O. Forming the current of underground metal pipelines by the highfrequency components of cathodic stations output signal / O.O. Aziukovskyi, D.V. Tsyplenkov // Гірнича електромеханіка та автоматика. - 2015. - № 94. - С. 123-129.

6. Aziukovskyi A. The electrochemical cathodic protection stations of underground metal pipelines in uncoordinated operation mode / A. Aziukovskyi // CRC Press. Balkema is an imprint of the Taylor \& Francis Group, an informa business, London, UK 2013- P. 47 - 55.

7. Азюковський О.О. Визначення струму стікання 3 підземного трубопроводу 3 врахуванням основних джерел збурень для підземних металевих комунікацій / О.О. Азюковський // Гірнича електромеханіка та автоматика. - 2018. - № 99. - С. 19-24.

8. Азюковський О.О. Система електрохімічного захисту від корозії з адаптацією до зміни електротехнічних параметрів об’єкту захисту / О.О. Азюковський, М.В. рогоза, С.М. Якимець // Електромеханічні і енергозберігаючи системи. 2018 - № 4 - С. 60 - 67.

\title{
SEASONAL INFLUENCE ON THE OPERATION MODES OF THE ELECTROTECHNICAL CORROSION PROTECTION SYSTEM
}

\author{
Aziukovskyi Oleksandr
}

\begin{abstract}
This article discusses the change in the magnitude of the currents of cathodic protection stations with changing seasons. The change in the value of currents at a constant voltage of the stations is significant. The work draws attention to the fact that with excess current, wasteful use of resources is possible. Given that changes in electrical parameters are possible not only with changing seasons, but also under the influence of precipitation, groundwater level, technological factors, it is advisable to automatically control the cathodic protection station. The use of joint control by several cathodic protection stations is proposed, which will minimize their combined influence. Coordination of the operating modes of the stations is minimizes the wasteful use of resource.
\end{abstract}

Keywords: CATHODIC PROTECTION STATION, STEEL PIPELINE, ELECTROCHEMICAL CORROSION, PIPELINE CURRENTS, PIPELINE TRANSPORT.

\section{Reference}

1. Network of gas mains and distribution pipelines of Ukraine »[Online]. Available: https://104.ua/en/gas-map. [Accessed: 0601 2020]. 
Ministry of Education and Science of Ukraine

The National Metallurgical Academy of Ukraine, Dnipro, 17 - 19 March, 2020

2. "State Statistics Service of Ukraine," [Online]. Available: http://www.ukrstat.gov.ua/. [Requested date: 0801 2020]

3. Strizhevsky I.V. Theory and calculation of the impact of the electrified railway on underground metal structures. / I.V. Strizhevsky, V.I. Dmitriev. - M.: Mechanical Engineering, 1967 - 227s.

4. Aziukovskyi O. Changing the Electrotechnical Parameters of an Underground Metal Pipeline Under the Influence of the High-Frequency Component Voltage of Cathodic Protection Stations / O.O. Aziukovskyi // Electrification of transport. Dnipropetrovsk National University of Railway Transport named after Academician V. Lazaryan. No. 10, 2015. p. 98-106

5. Aziukovskyi O. O. Forming the current of underground metal pipelines by the highfrequency components of cathodic stations output signal / O. O. Aziukovskyi, D. V. Tsyplenkov // Гірнича електромеханіка та автоматика. - 2015. - № 94. - С. 123-129.

6. Aziukovskyi A. The electrochemical cathodic protection stations of underground metal pipelines in uncoordinated operation mode / A. Aziukovskyi // CRC Press. Balkema is an imprint of the Taylor \& Francis Group, an informa business, London, UK 2013- P. 47 - 55.

7. Aziukovskyi O.O. Determination of runoff current from an underground pipeline taking into account the main sources of perturbations for underground metal communications / O.O. Aziukovskyi // Mining Electromechanics and Automation. - 2018. - No. 99. - P. 19-24.

8. Aziukovskyi O.O. System of electrochemical corrosion protection with adaptation to change of the electrotechnical parameters of the object of protection / O.O. Aziukovskyi, MV rush, SM Yakimets // Electromechanical and energy-saving systems. 2018 - No. 4 - P. 60 - 67. 